Rakenteiden Mekaniikka

Vol. 50, Nro 3, 2017, s. 114-117

https://rakenteidenmekaniikka.journal.fi/index

https:/doi.org/10.23998/rm.65342

(CKirjoittaja(t) 2017.

Vapaasti saatavilla CC BY-SA 4.0 lisensioitu.

\title{
Suurikaliiperisten aseiden tuliputkien pyörrevirta- tarkastuksen ja ultraäänitarkastuksen mekanisoinnin kehitys ja toteutus
}

Seppo Moilanen ${ }^{1}$, Ville Lehtinen

Tiivistelmä. Artikkelissa esitetään mekanisoitujen NDT-tarkastuslaitteiden suunnittelu, toteutus sekä tarkastusmenetelmäsuositus raskaiden ruutiaseiden tuliputkien turvallisen eliniän hallintaan liittyen. Kranaatinheittimen tuliputken sileä sisäpinta tarkastetaan kuivana sisäpuolisella pyörrevirtatarkastuksella (ET). Rihlatun tykinputken tilavuuden ja sisäpinnan tarkastukseen suositellaan ulkopuolista luotausta ultraäänimenetelmien yhdistelmällä (UT, ToFD) upotuksessa.

Avainsanat: tykit, kranaatinheittimet, tuliputket, käyttöikä, väsyminen, ainetta rikkomaton tarkastus, NDT, pyörrevirtatarkastus, ultraäänitarkastus, mekanisointi

Vastaanotettu 15.5.2017. Hyväksytty 4.6.2017. Julkaistu verkossa 21.8.2017.

\section{Taustaa}

Raskaiden aseiden tuliputket valmistetaan koneistamalla tavallisimmin lämpökäsitellyistä terästaeaihioista. Ne ovat ainepaksuuteensa nähden korkealujuuksisia ja sangen sitkeitä sekä isku- ja murtumissitkeyden että murtovenymän osalta etenkin perinteisten konstruktioteräksien ominaisuuksiin verrattaessa kuten viitteessä [1] ja sen alaviitteissä on todettu. Valmistusvaiheissa pyritään valmistusmenetelmillä ja ainetta rikkomattomilla tarkastusmenetelmillä (Nondestructive Testing, NDT) huolehtimaan siitä, että taeaihioissa ja valmiissa tuliputkissa ei esiinny sallittua alkukokoa suurempia sisäisiä tai pintaan avautuvia materiaalivikoja tai vikaryhmiä.

Palveluskäytössä tuliputket vaurioituvat ja ne hylätään joko kulumisen seurauksena tai - toivottavasti turvallisesti - ennen ennakoitua väsymisvauriota. Kulumista voidaan seurata sekä ballistisilla mittauksilla (ammuksen lähtönopeus, iskemähajonta jne. vs. ballistiset vaatimukset) että tuliputken geometrisilla mittauksilla [2]. Kulumisvaurio ei ole katastrofaalisen vaarallinen aseen miehistölle. Tuliputken väsymisvaurio saattaa joh-

${ }^{1}$ Vastuullinen kirjoittaja. seppo.moilanen(at)patria.fi 
taa putkimateriaalin äkilliseen murtumaan tai ruutikaasuvuotoon, jotka molemmat ovat vaarallisia tilanteita aseella ampuvan miehistön kannalta.

Sisäpuolisella paineella kuormitetun, jäännösjännityksettömän, paksuseinämäisen sylinterin (tuliputken) maksimijännitykset esiintyvät sisäpinnalla, jonne kohdistuvat myös laukauksen aikainen ruudin palokaasujen lämpökuormitus sekä ammuksen aiheuttamat mekaaniset kosketuskuormitukset. Tuliputken sisäpintaan syntyy varhaisessa vaiheessa lämpösäröverkko, joten tuliputken väsymiselinikää voidaan ennustaa lineaariselastisen tai elastis-plastisen murtumismekaniikan mukaisilla laskelmilla. On luonnollista, että tuliputkien palveluskäytönaikaiset NDT-tarkastukset painottuvat vian etsintään ja vikakoon arviointiin putken kriittiseltä sisäpinnalta ja sen läheisyydestä [7, 8].

Tuliputken sisäpinta voidaan tarkastaa silmämääräisellä tähystyksellä tai geometriamittauksilla, kuten mekaanisella kaliiperimittauksella tai laserkeilauksella [2]. Sisäpinnaltaan sileä putki voidaan särötarkastaa sisäpuolisilla NDT-menetelmillä kuten mekanisoiduilla pyörrevirtatarkastuksella (Eddy Current Testing, ET) [5], ultraäänitarkastusmenetelmillä (Ultrasonic Testing, UT) tai niiden yhdistelmillä. Rihlatun tykinputken sisäpinnan uritus ja käytönaikainen sisägeometrian muuttuminen kulumisen myötä vaikeuttavat sisäpuolisten mekanisoitujen NDT-tarkastusmenetelmien käyttöä tai estävät niiden käytön, joten rihlatun tuliputken sisäpinta on järkevää tarkastaa ulkopuolisilla ultraäänitarkastusmenetelmillä säröytymisen luotettavaa seurantaa ajatellen [7, 8]. Molemmissa tapauksissa epäilyttävät särötyyppiset vikanäyttämät on syytä varmentaa kulloinkin sopivilla NDT-lisätarkastusmenetelmillä, jottei synny vääriä päätelmiä tai aiheudu virheellisiä toimenpiteitä kuten tarpeettomia tuliputkien hylkäyspäätöksiä.

\section{Sileän tuliputken sisäpuolinen mekanisoitu pyörrevirtatarkastus}

Pyörrevirtatarkastuksessa pyörrevirta-anturin kelan vaihtuva jännite synnyttää kelan ympäristöön vaihtuvan magneettikentän, joka indusoi tarkastettavaan sähköä johtavaan kappaleeseen pyörrevirtoja. Pyörrevirtojen synnyttämän magneettikentän muutoksen aiheuttama impedanssivaihtelu kelassa on mitattavissa amplitudi- ja vaihemuutoksena [3, 4]. Amplitudin muutos on verrannollinen vikatilavuuteen ja vaiheen muutos vian sijaintiin, pintavian syvyyteen ja mahdolliseen vikatyyppiin. Tulosten luotettavuuden varmistamiseksi pyörrevirtatarkastuksessa pyritään sekä amplitudin että vaiheen muutoksien havainnointiin.
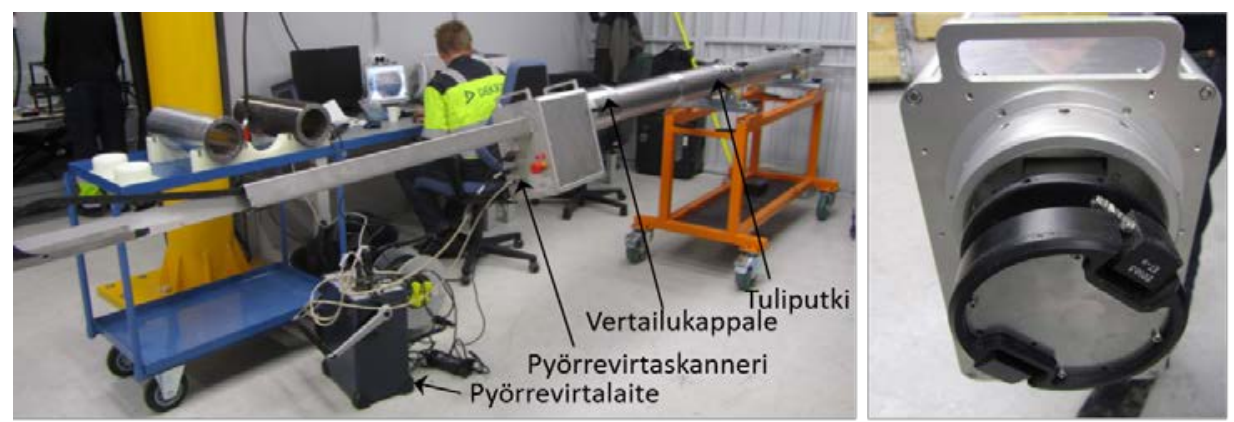

Kuva 1. Kranaatinheittimen tuliputken pyörrevirtatatarkastuslaitteisto, vasen kuva ja putken sisällä pyörivä anturipää, oikea kuva. Ristikäämiantureiden etäisyys putken sisäpinnasta pidetään vakiona hallitusti kuluvien anturisuojien laahatessa pintaa pitkin. Laitteiston säädöt ja toiminta varmennetaan vertailukappaleeseen kipinätyöstettyjen vertailuvikojen näyttämiin. 
Tuliputken valmistusvaiheen tarkastuksiin kehitetyllä kuvan 1 mukaisella mekanisoidulla pyörrevirtatarkastuslaitteistolla vikaindikaatio saadaan varmasti $a=0,25 \mathrm{~mm}$ syvyisistä ja matalammistakin sileään sisäpintaan avautuvista vioista. Sama laite soveltuu paljon ammuttujen rihlaamattomien tuliputkien sisäpinnan säröjen etsintään ja särökoon arviointiin. Koska pyörrevirtojen tunkeutuminen ferriittiseen materiaaliin on rajallista, ET-tarkastuksessa havaittujen syvien särönäyttämien koko on varmistettava paikallisesti näyttämäkohdan manuaalisilla lisätarkastuksilla kuten ulkopuolisilla perinteisillä UT-menetelmillä tai ToFD-menetelmällä (Time of Flight Diffraction, ToFD).

\section{Rihlatun tuliputken säröjen seuranta ultraäänitarkastustekniikoilla}

Alustavien NDT-menetelmäarvioiden ja kokeellisten tutkimusten perusteella [9] rihlatun tykinputken mekanisoiduiksi NDT-tarkastusmenetelmiksi valikoituivat perinteinen pulssikaiku-ultraäänitarkastus ja ToFD-tekniikka upotuksessa ulkopinnalta luotaamalla.

Pulssikaikuanturin lähettämä pitkittäisaalto taittuu veden ja tuliputken rajapinnassa ja osa muuttuu teräksessä eteneväksi poikittaisaalloksi. Putken seinämässä etenevä poikittaisaalto heijastuu seinämän epäjatkuvuuksista (esim. reunat tai viat) takaisin ja osa heijastuneesta poikittaisaallosta muuttuu jälleen teräs-vesi rajapinnassa pitkittäisaalloksi, joka havaitaan anturilla [3, 6]. ToFD-tekniikassa käytetään luotainparia, jossa lähettimen kohteeseen synnyttämän pitkittäisaallon heijastamat aallot havaitaan vastaanottoluotaimella. Putken sisäpinnasta saadaan voimakas heijastuma ns. takaseinäkaiku ja vikojen kärjistä diffraktioaallot, joiden avulla vikojen syvyydet voidaan määrittää.

Menetelmien havaitsemiskyvyn ja -herkkyyden arvioimiseksi valmistettiin koekappaleet 2500 laukausta ammutun tykin tuliputkesta. Kappaleet irrotettiin rihlattoman panoskammion ja sen jälkeisen rihlatun työlieriön alueilta. Koekappaleiden sisäpinnoille valmistettiin kipinätyöstöllä vertailuvikasarjat. Koekappaleet luodattiin UT-tarkastusmenetelmillä, tosin vain yksi menetelmä kerrallaan, ja talletetut tarkastusdatat analysoitiin UT-datan käsittelyohjelmilla simuloiden mekanisoitua tuliputken tarkastusta [9, 10].
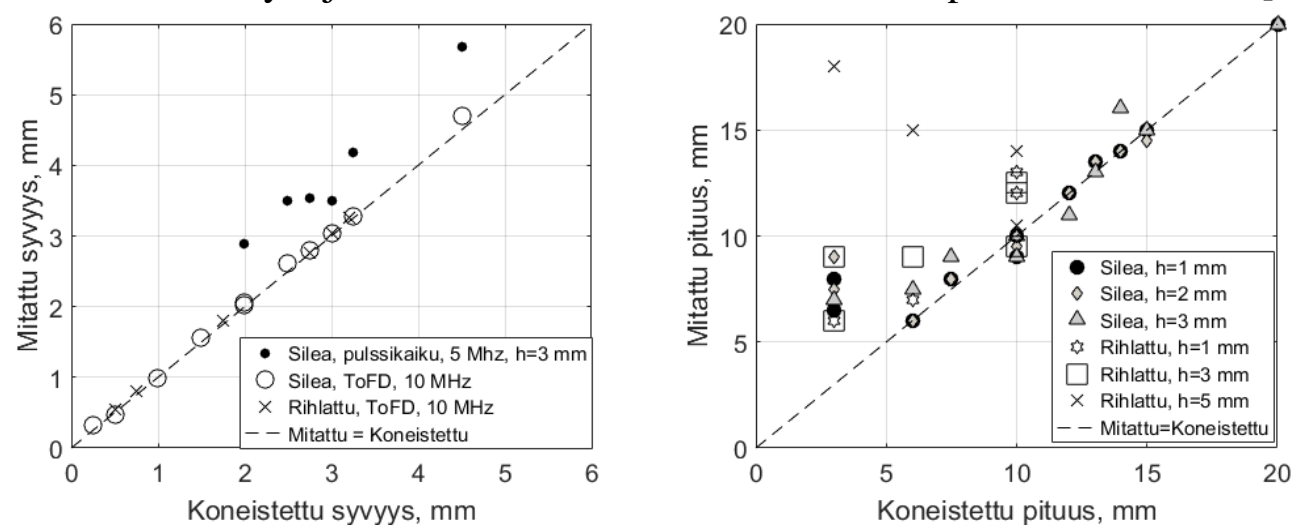

Kuva 2. Tykin tuliputken koekappaleiden ultraääniluotaustulos vs. vertailuvian koneistusmitta viiteraportin [10] mukaan. Vian syvyystulokset pulssikaiku- ja ToFD-luotauksella, vasen kuva. Vian pituustulokset pulssikaikuluotauksella, oikea kuva. $h$ on luotauslinjojen etäisyys.

Kuvassa 2 esitetyn vikanäyttämien mittaustulosten ja koneistusmittojen vertailun mukaan vertailuvian syvyys ja pituus yliarvioitiin konservatiivisesti lähes kaikissa tapauksissa pulssikaikutekniikalla. Rihlatulla osalla vian syvyyttä ei kyetty arvioimaan 
pulssikaikutekniikalla, mutta syvyys saatiin varsin tarkasti ToFD-luotauksella sekä panoskammion sileältä että tuliputken työlieriön rihlatulta osuudelta.

Tulosten perusteella suositellaan, että tykin rihlatun tuliputken mekanisoidussa ultraäänitarkastuksessa sisäpinnan viat etsitään ja luokitellaan alustavasti pulssikaikutekniikalla, jolla määritetään myös vikojen pituudet. Säteen suuntaisella normaaliluotauksella [7, 8] pyritään saamaan lisävarmistus vikanäyttämästä. Kynnysrajan ylittävien näyttämien syvyydet määritetään ToFD-luotauksen datasta. Luotauslinjojen etäisyydeksi suositellaan $h \approx 3 \mathrm{~mm}$. Mekanisoidut luotaukset tehdään samanaikaisesti yhdellä ajolla.

\section{Viitteet}

[1] S. Moilanen. Suurikaliiperisten ruutisaseiden tuliputkien lujuus- ja materiaaliteknisiä kehitysnäkymiä. Julkaisussa: H. Koivurova \& M. Malaska. (toim.) Proceedings of the $11^{\text {th }}$ Finnish Mechanics Days. University of Oulu: 195 - 201, 2012.

[2] M. Hartas, J. Romeo, and J. Doyle. The application of laser measurement to reduce wholeof-life ownership costs of large calibre gun barrels. QinetiQ Australia. Mawson Lakes, Adelaide, SA. 2016. 4.4.2017. https://www.slideshare.net/MichaelHartas/the-applicationof-laser-measurement-to-reduce-whole-of-life-ownership-costs-of-large-calibre-gunbarrels

[3] C. Hellier. Handbook of nondestructive evaluation. McGraw-Hill Companies, Inc. 2003. doi: 10.1036/007139947X

[4] J. Hansen. The eddy current inspection method. Parts 1-4. Back to basics. Insight. 46(5-8): 2004.

[5] D. Concordia. Eddy current inspection of gun tubes. U.S. Army ARDEC, Technical report ARCCB-TR-92034, Picatinny Arsenal, NJ. 1992.

[6] M. Berke. Ainetta rikkomaton ultraäänitarkastus. Johdatus perusteisiin. Krautkrämer. Sonar Oy, Espoo. 27.4.2017. http://www.sonar.fi/wp-content/themes/sonarfitheme/ohjeet/ultraaanitarkastus.pdf

[7] J. J. Miller, D. C. Winters, and R. R. Fujczak. The measurement and analysis of fatigue crack growth in thick-walled cylinders. Benet Weapons Laboratory, Watervliet Arsenal technical report WVT-TR-74040. Watervliet, N.Y. 1974. ADA-000689

[8] G. Wulf. Use of ultrasonics to determine the crack size in high strength gun barrels. Department of Defence. Materials Research Laboratories report MRL-R-953. Melbourne, Victoria. 1985.

[9] V. Lehtinen. Tykin tuliputken NDT-esiselvitys. Dekra Industrial Oy luottamuksellinen ja julkaisematon raportti. Tampere. 2015.

[10] V. Lehtinen. Näyttämäherkkyyden ja vikakoon erottelukyvyn teoreettis-kokeellinen arviointi. Dekra Industrial Oy luottamuksellinen ja julkaisematon raportti. Tampere. 2016.

Seppo Moilanen

Patria Land Systems Oy, Hatanpään valtatie 30, FI-33100 Tampere, Finland

seppo.moilanen(at)patria.fi

Ville Lehtinen

Dekra Industrial Oy, Nuutisarankatu 15, FI-33900 Tampere, Finland

ville.lehtinen(at)dekra.com 